\title{
The Presence of Polish Academics on Social Networking Websites for Academics, Using the Example of Employees of Nicolaus Copernicus University
}

\author{
Beata Stachowiak \\ Faculty of Political Studies and International Relations, Nicolaus Copernicus University, Torun, Poland \\ *Corresponding Author: beata.stachowiak@umk.pl
}

Copyright (C 2014 Horizon Research Publishing All rights reserved.

\begin{abstract}
The purpose of this article is to present the opportunities provided for researchers and academics by social networking websites in the context of their professional work. Moreover, the paper discusses the level of penetration of social websites by Polish academics on the example of Nicolaus Copernicus University (NCU) researchers. The results indicate that the level of presence of Polish academics on the academic social networking sites is small. Also, noticeable are the differences between the representatives of various areas of science. The author reflects on the reasons for such poor presence of Polish academics in the academic cyberspace.
\end{abstract}

Keywords Social Networking Websites, Universities, Academics, Poland

\section{Introduction}

The emergence and development of social media has contributed to changes in human life, including in the area of professional work. The profession of an academic teacher is no exception. Social media, including social networking websites are the subject of extensive exploration and research that leads to development of the statistical portrait of the user (Universal McCann reports ${ }^{1}$, Eurostat study ${ }^{2}$, the Public Opinion Research Center research ${ }^{3}$, the Social Diagnosis project ${ }^{4}$ ), and to a description of the impact of

1 Since 2006 Universal McCann has been examining the activity in social media of internet users around the world; materials of the study are available online at: http://www.universalcann.de

2 Eurostat is an European institution which collects statistical results from the European Union in a number of areas, including the information society and social media use; detailed statistics at: http://epp.eurostat.ec.europa.eu/ portal/page/portal/information society/data/database

3 The Public Opinion Research Center (CBOS in Polish) established in 1982 , is a research center that conducts representative research and surveys of Polish society in the areas of social, political and economic life. The Public Opinion Research Center also conducts research in the area concerning the development of the information society. The reports prepared by the center are available at:

http://www.cbos.pl/PL/publikacje/publikacje.php

4 Social Diagnosis is a research project that has been carried out since 2000 . social media on the lives of its users [1,2]. However, the topic of social media use by universities and academics is relatively seldom discussed $[3,4,5]$.

The results of the aforementioned research in the area of use of social websites brings an important message for the academics from Polish universities. It is a message that cannot be overlooked in the planning of one's professional activities. First, $90 \%$ of students use social media. Second, Polish universities are beginning to perceive the need for use and diversification of social media in their academic communication and the promotion of the university. Third, the use of social media transforms the way of communication in the world of science and the way of communication between teacher and student, changing their relationships.

These facts lead to one basic conclusion: academics must include this communication channel into many areas of their activity.

\section{Social Networking Websites for Academics}

Social networking websites targeted to academics offer many possibilities. But, so far they are not fully appreciated by the academic community, including researchers in Poland. Properly used, social websites allow for the dissemination of research results, for promotion of scientific research institutions, for participation of academics in the broad academic discourse. Having a profile on the academic social networking website can contribute to greater recognition of a researcher outside the local society, to growth in numbers of one's work citation, and to the popularization of one's achievements. The use of social media by the university may have a positive result in recruitment results or in the reach to a larger group of potential recipients of research. Currently,

In the framework of the project conducted is a comprehensive analysis of data concerning households, attitudes, behavior, and state of mind of the members of these households. The reports are available at: http://www.diagnoza.com. 
there are many social networking websites where one can establish a profile presenting one's professional achievements. Websites such LinkedIn ${ }^{5}$ and Profeo.pl can serve as an example. Especially dedicated to academics are: ResearchGate, ${ }^{6}$ ResearcherID, ${ }^{7}$ and Index Copernicus Scientists. ${ }^{8}$ We will briefly characterize all of them, and also look closer at ResearchGate as this website was the most popular among the studied population.

Table 1. Numerical characteristics of ResearchGate

\begin{tabular}{|c|c|c|c|}
\hline Area of science & $\begin{array}{c}\text { Number of } \\
\text { registered } \\
\text { academics }\end{array}$ & $\begin{array}{c}\text { Number of } \\
\text { reported } \\
\text { publications }\end{array}$ & $\begin{array}{c}\text { Mean number of } \\
\text { registered } \\
\text { publications }\end{array}$ \\
\hline Humanities & 232,250 & $1,560,527$ & 6.72 \\
\hline Social science & 533,305 & $3,945,599$ & 7.40 \\
\hline Exact science & 467,702 & $7,534,146$ & 16.11 \\
\hline Natural science & 682,206 & $9,981,411$ & 14.63 \\
\hline $\begin{array}{c}\text { Engineering } \\
\text { science }\end{array}$ & 502,267 & $6,078,941$ & 12.10 \\
\hline $\begin{array}{c}\text { Agriculture, } \\
\text { Forestry, and } \\
\text { Veterinary }\end{array}$ & 205,409 & $1,807,719$ & 8.80 \\
\hline $\begin{array}{c}\text { Medical, Health, } \\
\text { and Physical } \\
\text { Education } \\
\text { sciences }\end{array}$ & 729,350 & $7,973,228$ & 10.93 \\
\hline Fine Arts & 85,239 & 352,955 & 4.14 \\
\hline
\end{tabular}

Source: Own calculations based on data from ResearchGate (July 2013).

ResearchGate is a website with global reach, addressed to scientists and academics of all disciplines. In early July 2013, the website had over 3,000,000 registered users (an increase from December 2012 of approximately 700,000 people), and contains millions of publications. Table 1 contains a numeral description of the ResearchGate website according to areas of knowledge as classified by Polish legislation [6]. A quantitative analysis indicates that between representatives of the various areas of knowledge there are differences in terms of, for example, numbers of the published on the website publications.

On ResearchGate, as well as on other social sites, each user creates their own profile where one can publish his or her scientific papers, reports and articles. Users of ResearchGate also have the option to use a virtual library of academic papers and abstracts. The publications available on site include major databases and more than a thousand open access documents. Besides, ResearchGate has other features that are distinctive for social networking sites, such as the possibility of exchanging messages in the network, posting on chat rooms and asking questions. Some scientific and research organizations use this portal to communicate with

5 LinkedIn is a social networking website created for professionals, offering recruitment solutions. Available at: http://www.linkedin.com.

6 ResearchGate is a website available at: http://www.researchgate.net/.

7 ResearcherID can be found at: http://www.researcherid.com.

8Index Copernicus Scientists is available at: https://scientists.indexcoperni cus.com/. their members. ResearchGate offers also a system for recommending publications that are similar to the topics and areas of studies of the person who recommends a particular publication, as well as a system of finding and recommending other users with a similar research area. Users of ResearchGate obtained a multivariable RG score that depends on the number of publications, number of people following a particular person, as well as the activity of a person in the discussions.

ResearcherID is another social networking website targeted at scientists and researchers. Again, each user of the website creates a profile. The website's tools allow for finding documents using criteria of the researcher's name, disciplines or countries. However, the procedure of presentation of one's academic work is a bit cumbersome, and the process of uploading of papers is quite complex. Another option for a researcher is to become a member of Index Copernicus Scientists. The user creates his or her academic profile. Moreover, the website creates an objective assessment of scientific achievements based on complex, multivariable, and patented algorithms. The authors of this internet project inform also that for every researcher the website automatically creates a list with information about potential collaborators in the implementation of research or in writing new publications from the studied area, as well as the list of available grants, and organized meetings and conferences.

From the point of view of an academic teacher, it is preferable to have two to three profiles on the networking websites targeted at scientists and researchers. For contact with students it is advisable to use any of the social networking sites of a general public. It is advisable that for communication on grades or other official issue, academics should use more formal tools, such as USOS ${ }^{9}$.

\section{Research Methodology}

The research was conducted at the beginning of July 2013 and utilized the online database of Nicolaus Copernicus University employees. The database showed that at that time 2,090 people were employed on teaching and research contracts. The content of the database was compared with lists of people who have affiliated to the NCU profile on one of the three aforementioned academic social networks. In addition, we conducted interviews with several employees of NCU. These interviews were designed to identify the opinions of academics on the social networking sites.

Nicolaus Copernicus University has 17 faculties. In the academic year of 2012/2013, NCU educated nearly 30,000 students in 82 majors. For several years, Perspektywy magazine has ranked Nicolaus Copernicus University in Torun fifth among Polish universities. According to the SIR World Report 2013, Nicolaus Copernicus University in

9 The University Study-Oriented System (called USOS) is a computer system used to manage the course of study in higher education schools. It also allows users to communicate between each other. 
Torun takes 742nd position among the higher education institutions, is 25th in the Eastern Europe region and fourth among Polish universities [7]. The Webometrics Ranking of World's Universities ranked NCU at 709th position in the world, ninth position among Polish higher education schools, and gives it fifth place among Polish universities, and 283rd in the ranking of European universities [8]. One can say that Nicolaus Copernicus University is an average class university in Poland, although between the departments are qualitative differences in the publication and scale of cooperation with other institutions. The important information is that in 2004 the Medical University was included into Nicolaus Copernicus University.

ResearchGate website ranked Nicolaus Copernicus University in Torun (as of July 2013), 668th in the world ranking list and 329th in the European ranking, giving it an RG score of 3,777.02 (RG score as of 24 July 2013). However, in the case of Polish traditional universities, NCU took the third place. ResearchGate also uses the positioning based on Impact Points. NCU obtained a value of 3,480.09 which classified it ultimately at 1,493rd place in the world ranking, 578th place in European ranking, 14th place among Polish academic and research institutions, and sixth place among the traditional universities.

\section{Results}

The comparison of academic social website users claiming their affiliation to NCU with the NCU employees database showed that the most popular website among NCU employees is ResearchGate. Two hundred and ninety-two academics from NCU (13.97\% of all employees) were registered on ResearchGate, 54 employees were registered on ResearcherID ( $2.58 \%$ of all employees) and 52 persons were registered on IndexCopernicus $(2.49 \%$ of all employees).
A quantitative analysis of the data from Table 2 showed that the most numerous representations on ResearchGate were the Faculty of Medicine (53 profiles) and the Faculty of Biology and Environmental Protection (47 profiles). The third place in terms of numbers of employees' profiles was the Faculty of Pharmacy (40 profiles). It is worth noting that before the 2004 two of these departments were part of the Medical University. When analyzing academics' activity in terms of the percentage of participation in social websites of employees from the particular faculties, the equation changed slightly: the most active was the Faculty of Biology and Environmental Protection (39.8\%) and the Faculty of Mathematics and Computer Science (31.4\%). The penetration rate in these faculties exceeds $30 \%$. The indicator describing the percentage of employees that have a profile on ResearchGate that exceeded $20 \%$ were noted also among employees of the Faculty of Chemistry (27.38\%), the Faculty of Pharmacy (26.32\%), and the Faculty of Physics, Astronomy and Applied Computer Science (24.24\%). It is clear that participation in social networks of these faculty employees exceeds the average indicator oscillating around $14 \%$. There are, however, faculties that are represented residually, the number of representatives doesn't exceed ten or even five people. One of the departments is not represented on the ResearchGate website at all: this is the Faculty of Theology.

In the case of social websites such as IndexCopernicus and ResearcherID, the activity of the academics from NCU is much lower and some faculties don't have their representatives at all. The visibility of Nicolaus Copernicus University would be weaker if not for the presence on social websites of employees from two faculties that before 2005 had belonged to the Medical University. This state is disturbing because it is a manifestation of the fact that academic marketing is treated with the secondary importance.

Table 2. Data concerning the participation of researchers and academics from Nicolaus Copernicus University in the academic networks

\begin{tabular}{|c|c|c|c|c|c|c|c|c|c|}
\hline Name of the faculty & $\mathrm{A}$ & $\mathrm{B}$ & $\mathrm{C}$ & $\mathrm{D}$ & Name of the faculty & $\mathrm{A}$ & $\mathrm{B}$ & $\mathrm{C}$ & $\mathrm{D}$ \\
\hline $\begin{array}{c}\text { Faculty of Biology and Environmental } \\
\text { Protection }\end{array}$ & 118 & 47 & 10 & 8 & $\begin{array}{c}\text { Faculty of Economic Sciences } \\
\text { and Management }\end{array}$ & 113 & 5 & 3 & 3 \\
\hline Faculty of Chemistry & 95 & 26 & 11 & 0 & Faculty of History & 138 & 16 & 1 & 0 \\
\hline Faculty of Pharmacy & 152 & 40 & 1 & 9 & Faculty of Health Sciences & 237 & 21 & 0 & 10 \\
\hline Faculty of Languages & 172 & 7 & 3 & 0 & Faculty of Earth Sciences & 59 & 3 & 2 & 0 \\
\hline $\begin{array}{c}\text { Faculty of Physics, Astronomy and } \\
\text { Applied Computer Science }\end{array}$ & 132 & 32 & 15 & 0 & Faculty of Educational Sciences & 55 & 6 & 1 & 0 \\
\hline Faculty of Humanities & 65 & 2 & 0 & 0 & $\begin{array}{c}\text { Faculty of Political Studies and } \\
\text { International Relations }\end{array}$ & 59 & 1 & 2 & 1 \\
\hline Faculty of Medicine & 315 & 53 & 0 & 19 & $\begin{array}{c}\text { Faculty of Law and } \\
\text { Administration }\end{array}$ & 112 & 2 & 0 & 0 \\
\hline $\begin{array}{c}\text { Faculty of Mathematics and Computer } \\
\text { Science }\end{array}$ & 86 & 27 & 5 & 1 & Faculty of Fine Arts & 146 & 4 & 0 & 1 \\
\hline Faculty of Theology & 36 & 0 & 0 & 0 & & - & - & - & - \\
\hline
\end{tabular}

Description of columns: A - number of faculty's employees, B - number of employees who have ResearchGate profile, C - number of employees who have profile on ResearcherID, D - number of employees who have their profile on IndexCopernicus. 
The absence of academics on social networking websites is a manifestation of a broader phenomenon that includes the reluctance of academics to use ICT tools in academic work and a manifestation of conviction that electronic publications are less valuable types of publications. The diagnosis of Edwin Bendyk from 2009, in which he stated that Polish science barely escapes from the modernist model of communication, sill remains valid [9]. However, properly used, social media allows for the promotion of knowledge, for participation in public discourse, but also for initiation of important discussions.

Another issue that cannot be missed is the fact that even young academics have relatively little experience in publishing electronic versions of their papers. Research among students of doctoral programs indicated that most of them do not have any experience in the field of e-publishing, since $63 \%$ of respondents had never published their papers in this form [10]. Yet, analysis of the world's scientific journals indicates developing digitization of scientific periodicals. According to the British Library report with regards to British journals, by 2020, the share of journals published only in the electronic version will increase to $60 \%, 35 \%$ of journals will be hybrid, and only $5 \%$ will have the print version. Thus, as much as $95 \%$ of journals will have a digital version [11].

The similitude of scores that Nicolaus Copernicus University obtained in the assessment generated by ResearchGate with ranks obtained in the Webometrics Ranking of World's Universities, SIR World Report, or in the Perspektywy ranking in the category of traditional universities in Poland, is not a coincidence. Although in all these ratings different methodologies were used, some components were similar, which led to the same conclusions. This gives us a reason to believe that the conclusions formulated for the studied population can be extended to other universities in Poland. Polish higher education institutions maintained the status quo, but other universities around the world "do not let grass grow under their feet" and most of them care about their visibility in digital space. Polish universities, and not only the traditional universities, seem to be stagnant. This is evidenced by the fact that in August 2013, only three Polish universities were among the 500 most web-visible higher education institutions in the world [9]. Six months ago, among the top 500 were seven Polish universities. Also in European ranking, Polish universities do not take forefront places in visibility on the web. First among Polish universities is the University of Warsaw, being 87th in the European Union. The academic marketing is not taken seriously not only by NCU, but also among the capital's universities within Poland.

The complementing data for this research is comprised of the results of surveys with the university's employees. Interviews with 18 persons were conducted. Among them 12 persons did not have profiles on academic networking websites. The survey research was thought as an introduction for further research. People without a profile on one of the social networking websites for academics were asked for the reason of such a situation. The answer included: lack of knowledge about such services, aversion to social networking sites, low confidence in one's skills in the use of ICT, no requirements for such action from supervisors, lack of conviction about the benefits of having such a profile. Some people declared that although, in their own assessment, they have good ICT skills, they are already obligated to carry out continuous reporting, and to maintain a profile on a social network will be yet another obligation. They also admitted that if the university's administration used social networking profiles to draw from it information for reporting, they would establish such a profile. Some of the interviewees believed that even doubling the data sent to the section of bibliometrics was unnecessary. The reason for not having a profile was also the fear of confronting other researchers and academics. Two social sciences academics indicated that from the point of view of competitiveness they would be afraid of getting a low rate of Impact Factor in comparison with those from other areas of science. But we are observing a slowly growing opposition against this index and the academic world seeks to define other multivariable measures [12]. Although, the scientific achievements cannot be described in one number. There were also opinions that having such a profile is not appropriate, and promoting oneself is not completely approved.

People who have a profile on social networking websites indicated that the profile was created on their own initiative; they were not encouraged by their supervisors. Some people learned about the possibility of having a profile on a social network from their friends. The creation of such a profile positively affected how they put in order their professional achievements. People with a profile on social networking websites for academics pointed to the benefits such as proposals to publish in scientific journals from other countries, the opportunity to exchange views with others research centers even from distant countries. They also noted the possibility to compare their own achievements with academics from other research centers. It was also stressed that the multivariable assessment generated by social networks is sometimes different than the assessments made by faculty bodies. One respondent saw in academic social networks an opportunity to find other or an additional work. In all conversations people expressed some dissatisfaction that efforts to promote the university by promoting the employees' achievements are not appreciated by supervisors.

\section{Conclusion}

To say that academics should not ignore social networking sites does not mean that they should use all available opportunities. When deciding which service one should use, one must not only take into account the needs and preferences of recipients but also one's own abilities and skills. And above all, what one has to say in the scientific discourse. It would be advisable to conduct SWOT analysis before making a decision on which social networking site 
one should choose.

Means of Information and Communication Technology are tools used in the professional work of academics. The use of tools cannot be regarded as the goal itself, because then it is perceived as something artificial or imposed. It should be remembered that there is a difference in using various types of media; for example maintaining one's own website is less formal and more "emotional" than having a profile on a social networking site.

There are many advantages for academics of using social networking websites. First of all, whether someone likes it or not, the vast majority of modern students are active and operate in this environment. Second, education should prepare young people to be active in their work, in which information and communication technologies, including those that allow one to transform communication into an interactive dialogue, play a significant role. Third (and this regards especially teachers of generation X), the use of new means of communication in professional work not only requires reflection and the acquisition of new skills, but also allows one to break the routine, dismiss the feeling of burnout, which occurs especially after 20-30 years of professional work. Fourth, the use of social media is certainly an activity that popularizes one's work and as such should be taken into account in the evaluation of academic teachers. Sometimes, running a website for students or an academic blog requires greater involvement and consistency than writing a popular scientific article. Fifth, in countries where spending on education is negligible, social networking sites for academics open a door to share the results of one's professional research beyond the local society. (In Poland in 2012, expenditures for research and development amounted to $0.39 \%$ of GDP, compared to the $2 \%$ of the EU average and $4 \%$ in Finland.) Unfortunately, publishing in international journals often means paying fees to publications, and some departments are unprepared for such costs. Therefore, researchers and academics should strive to ensure that they gain maximum benefits from social networking websites for academics. Sixth, academics especially those from the field of humanities and social sciences should become more active in popularizing their work; dissemination of knowledge is an important requirement in the proceedings to get promotion. And although lectures and articles are important, they do not translate into one's presence outside one's backwater. The way to popularize one's work is through the global network.

\section{REFERENCES}

[1] C. Fake, FOMO and Social Media, Online available from http://caterina.net/2011/03/15/fomo-and-social-media/.

[2] S. Turkle, Connected but alone, Online available from http:// www.ted.com/talks/sherry_turkle_alone_together.html.

[3] H. Shema, J. Bar-Ilan, M. Thelwall, Research Blogs and the Discussion of Scholarly Information, PLoS ONE 7(5): e35869. doi:10.1371/journal.pone.0035869

[4] E. Kulczycki, Wykorzystanie mediów społecznościowych przez akademickie uczelnie wyższe w Polsce. Badania w formule otwartego notatnika, Online available from http://hdl.handle.net/10593/2853.

[5] B. Stachowiak, Nauczyciel akademicki a media społeczności owe, e-mentor 3/2013, Online available from http://www.e-mentor.edu.pl/artykul/index/numer/50/id/1024.

[6] The Ordinance of Minister of Science and Higher Education of 8 August 2011 on the areas of knowledge, fields of science and arts and on scientific and artistic disciplines, Online available from

http://isap.sejm.gov.pl/DetailsServlet?id=WDU2011179106 5 .

[7] SIR Global 2013-Higher Education-Rank, Online available form http://www.scimagoir.com/pdf/SIR\%20Global\%20201 $3 \% 20 \mathrm{HE} \% 20 \mathrm{O}$.pdf.

[8] Webometrics Ranking of World Universities, Online available from http://www.webometrics.info/en/search/Rank ings/Nicolaus\%20type\%3Aregion.

[9] E. Bendyk, Wiedza dla wszystkich?, [in] Przewodnik po otwartej nauce, [eds] J. Hofmokl, A. Twardowski, B. Bednarek-Michalska, K. Siewicz, J. Sprosta,Warsaw 2009.

[10] P. Milewska, Publikacje elektroniczne w pracy młodego naukowca. Analiza wyników badań ankietowych przeprowadzonych na terenie województwa łódzkiego, [in] Publikacje elektroniczne w rozwoju nauki polskiej, [ed] Maria Czyżewska, Bialystok 2012, pp. 33-44.

[11] M. Nahotko, Polskie naukowe czasopisma elektroniczne: stan obecny, [in] Publikacje elektroniczne w rozwoju nauki polskiej, [ed] Maria Czyzewska, Bialystok 2012, pp. 81-92.

[12] J. Kaiser, In 'Insurrection,' Scientists, Editors Call for Abandoning Journal Impact Factors, Online available from http://news.sciencemag.org/2013/05/insurrection-scientists-e ditors-call-abandoning-journal-impact-factors. 